\title{
FAMILY LAW - SOLIDARITY OR DISARRAY?
}

\section{Bill Atkin*}

Professor Gordon Anderson and labour law are synonymous in New Zealand. Gordon has provided a vision for the future of labour law. This article is offered in a similar spirit. It was prepared for a conference on "The Future of Family Law", held in Auckland on 20 September 2018 with distinguished guest, Lady Brenda Hale, President of the United Kingdom Supreme Court. The history of family law in New Zealand is full of remarkable landmarks. Many align with the rights of various groups: children, women, Māori, those with intellectual disabilities, LGBTI+ communities and abuse victims. If we dig deeper, we find that the various parts do not make a very coherent and harmonious whole. The law is tugged in different directions. This article draws on the concept of "family solidarity", refashioned for New Zealand purposes as "family and community solidarity". Could this help develop a unifying theme? Could it form the basis for future family law reform? Developments such as legislation on child poverty reduction, the Ministry for Children and relationship property law are briefly explored.

\section{INTRODUCTION}

In many ways the history of family law is one of progress. The line of achievements continues to rise with the recognition, among other things, of children's rights, of diversity, and of the need to tackle the insidious levels of abuse. Yet, significant blips can also occur in the line. The review of the family justice changes made in 2014 illustrates this perfectly. ${ }^{1}$

Further, the law does not always follow the same line of progress. We have two major pieces of legislation dealing with the care of children that rather awkwardly tug in different directions: the Care of Children Act 2004 (COCA) and the Oranga Tamariki Act 1989 (OTA), with its

* Professor of Law, Victoria University of Wellington, New Zealand. Special thanks to those who provided feedback including those who attended a staff seminar where the original paper was first presented.

1 Ministry of Justice Te Korowai Ture a- Whānau: The final report of the Independent Panel examining the 2014 family justice reforms (May 2019). The author was a member of the Panel's Expert Reference Group. 
alternative English title the Children's and Young People's Well-being Act 1989. In addition there is the Children's Act 2014, originally entitled the Vulnerable Children Act 2014.

In the financial area, the approaches to property and maintenance are very different and child support sits as an outlier within the Inland Revenue Department. On child support, in words that we can apply to New Zealand, Lady Hale said: "we have now separated the financial and caring responsibilities of parenthood, and I wonder how far this really serves the children's interests". ${ }^{2}$

There is a sense in which the various parts of family law do not make a very coherent and harmonious whole. ${ }^{3}$ This is likely to be because we are unclear about the underlying driving principles. While the United Nations Convention on the Rights of the Child has widespread acceptance, we are less sure about other concepts. ${ }^{4}$ In this article, I wish to promote the idea of family solidarity as the basis for developing a unifying theme, or what I have labelled "family and community solidarity". In a new edition of my book on relationship property, against the backdrop of the New Zealand Law Commission's recent project on the topic, ${ }^{5}$ I suggested that family solidarity be the starting point in terms of the values that should form the basis of law reform: "[t]his concept means that we take seriously the domestic relationships that people form and not treat the parties like strangers or individual agents." ${ }^{6}$ Other approaches are possible. For example, some people will favour a much more laissez faire approach, others will focus on autonomy, others on dependency and vulnerability, and others with an emphasis on caring. ${ }^{7}$ Gillian Douglas has just published an important book entitled Obligation and Commitment in Family Law, ${ }^{8}$ the title itself conveying much of the philosophy.

I have focused on family solidarity because it has synergies with distinctive aspects of legal policy in Aotearoa New Zealand, in particular indigenous Māori culture. It also has a positive ring in contrast to a lot of family law that sounds negative because it is often about relationship breakdown. I also draw heavily on a special issue of the Child and Family Law Quarterly devoted

2 Lady Hale "The 8th ASARCO Annual Lecture 1997: Private lives and public duties: what is family law for?" (1998) 20 JSWFL 125 at 134.

3 I discussed this in Bill Atkin "Harmonising Family Law" (2006) 37 VUWLR 465.

4 Convention on the Rights of the Child 1577 UNTS 3 (opened for signature 20 November 1989, entered into force 2 September 1990).

5 Law Commission Review of the Property (Relationships) Act 1976: Te Arotake $i$ te Property (Relationships) Act 1976 (NZLC R143, 2019).

6 Bill Atkin Relationship Property in New Zealand (3rd ed, LexisNexis, Wellington, 2018) at [12.2].

7 See for example Jonathon Herring Caring and the Law (Hart Publishing, Oxford, 2013).

8 Gillian Douglas Obligation and Commitment in Family Law (Hart Publishing, Oxford, 2018). 
to "family solidarity". The lead article by Anne Barlow, law professor at the University of Exeter is a compelling account of family solidarity. She takes the view that: ${ }^{9}$

... there remains an important role for family law to play in regulating family life beyond any bilateral contract between partners and ... this should involve placing a positive, modernised reconceptualisation of family solidarity as a norm at the heart of family law.

And again: ${ }^{10}$

... a new approach which applauds and recognises the benefits and risks of engaging in the joint enterprise of family solidarity should be constructed to embody notions of equal value of different family roles and recognise the limits these (for good cause) place on the exercise of individual autonomy.

We can "applaud" this for many reasons, including the echoes that ring in s $1 \mathrm{~N}(\mathrm{~b})$ of the Property (Relationships) Act 1976 (PRA) to the effect that "all forms of contribution ... are treated as equal" - New Zealand law thus already has signs of family solidarity. Let us be blunt however: the approach has little or no truck with the formerly fashionable neo-liberal ideology that once prevailed. This does not mean that the language of individual rights is alien (the United Nations Convention is about children's "rights"), ${ }^{11}$ but it is not the dominant vehicle for assessing values in family law.

\section{WHAT IS FAMILY SOLIDARITY?}

"Family solidarity" is a phrase commonly used by continental Europeans where its heritage is longstanding. It is heard less in the common law world. Indeed, I have sometimes been bemused by it. Barlow argues in favour of a dynamic and revitalised model that resonates with contemporary issues: ${ }^{12}$

The term "family solidarity" is ... an evolving concept which encapsulates the joint enterprise, mutual support and obligations which modern family life (in all its different forms) encompasses from a moral and economic perspective and which is often reflected and reinforced in legal regulation. It stands in contrast to individualistic notions of autonomy and recognises the altruism which is often required to fulfil its demands.

Another contributor to the Child and Family Law Quarterly, Tone Sverdrup, Professor of Law at the University of Oslo, says: "[f]amily solidarity includes acting on the basis of what is best for

9 Anne Barlow "Solidarity, autonomy and equality: mixed messages for the family?" (2015) 27 CFLQ 223 at 225.

10 At 229.

11 Convention on the Rights of the Child, above $\mathrm{n} 4$.

12 Barlow, above n 9, at 224. 
the family as a whole and putting family interests ahead of self-interests."13 One of the key marks of family solidarity then is to put the family ahead of the individual. In New Zealand, one of the great challenges to conventional family came in the 1980 s with the Māori renaissance. ${ }^{14}$ It heavily influenced the passage of the Children, Young Persons, and Their Families Act 1989 (now OTA). To be frank, it has not greatly affected other legislation subsequently passed perhaps until the Children, Young Persons, and Their Families (Oranga Tamariki) Legislation Act 2017 and even that was riddled with controversy. ${ }^{15}$ The Māori vision of family and personhood is a contrast to the classic Westernised "nuclear family": the person "belongs" to whānau, hapū and iwi. ${ }^{16}$ A person gets meaning from this sense of family and from the cultural heritage that lies in whakapapa. The Europeans of the past who coined the phrase "family solidarity" may not have had Māori in mind or other cultures, such as Pasifika cultures that are increasingly important in the New Zealand context, but can we not do so under the Barlow "modernised reconceptualisation of family solidarity as a norm at the heart of family law"? ${ }^{17}$ I wonder whether whanaungatanga (family relationships) is not very similar to "family solidarity".

\section{THE PERILS OF FAMILY SOLIDARITY?}

\section{A "Patriarchy" in Disguise?}

The origins of the phrase "family solidarity" are steeped in the days of patriarchy. Is there a danger that, in using this language, we may be playing into the hands of those who still promote male headship, wifely submission, beating of children and heteronormative relationships within marriage? Is it a conservative anti-progressive fight-back?

The Barlow concept is an "evolving" one. ${ }^{18}$ While it is about values, it is not an approach that is stuck in the stone tablets of the past. To be of any use, it must relate to the real world and to the genuine policy choices that are being made. The synergies with tikanga Māori have already

13 Tone Sverdrup "Family solidarity and the mind-set of private law" (2015) 27 CFLQ 237 at 238.

14 See especially the game-changing report: Department of Social Welfare Puao-Te-Ata-Tu: The Report of the Ministerial Advisory Committee on a Māori Perspective for the Department of Social Welfare (Government Printer, September 1988).

15 Discussed later. The Bill was passed by a very narrow majority, with the then government support party, the Māori Party, voting against it. One of the main points of contention was the so-called "whānau first" policy, in particular whether priority should be given to placing a child taken into care with someone in the whānau, hapū or iwi: see Oranga Tamariki Act 1989 [OTA], s 13.

16 See Jacinta Ruru "Kua tutū te pueha, kia mau: Māori aspirations and family law policy" in Mark Henaghan and Bill Atkin (eds) Family Law Policy in New Zealand (4th ed, LexisNexis, Wellington, 2013) 57.

17 Barlow, above n 9, at 225.

18 At 224 
been noted: beyond this, it is a reminder that Sverdup's phrase "what is best for the family as a whole" is of general application. ${ }^{19}$ The approach is inclusive, not exclusive, and so the reality of de facto relationships is taken on-board. The same is true of same-sex relationships, as well as familial links with elder citizens. ${ }^{20}$ Gender implications are major considerations in a modernised concept of family solidarity. Indeed, the old patriarchal model where power and status rested with the husband could actually be seen as anti-solidarity in modern terms. This is because the husband was (in theory) the only party allowed to exercise autonomy, which is a very one-sided version of autonomy. The model of family solidarity as a joint enterprise does not fit with this.

The effects on children are also relevant. In 2007, Parliament voted overwhelmingly to abolish the parental "right" to correct children by using physical forms of punishment. ${ }^{21}$ This was not intended to be a panacea for all child abuse but it signalled more generally that children are not objects with no say until they reach adulthood. Rather, they are integral participants in the joint enterprise that is captured by the refashioned concept of family solidarity. We find this in statutory form in the guardianship rules in COCA. Under s 16, guardians (usually the parents) are to contribute to a child's development and determine important questions like schooling "for" or "with" the child. The preposition "with" gradually but surely takes over from "for". In Hawthorne $v$ Cox, the High Court emphasised that, as a child gets older, the guardianship role is more one of counsellor than decision maker. ${ }^{22}$ This is a far cry from a model that lets fathers beat their teenagers because they do not like what they say or do. ${ }^{23}$ Very arguably, these developments are all part of a modernised concept of family solidarity.

\section{B Abuse?}

A much more serious challenge to family solidarity is that the family can be a dangerous place. In New Zealand we have high levels of child abuse and domestic violence. The home is not always the safe place that the ideal conjures up. It could be argued that the family is the venue for "insolidarity" and insecurity, from which people need to be protected. The novelist, Maurice

19 Sverdrup, above n 13, at 238.

20 See from the special issue of the Child and Family Law Quarterly: Frederik Swennen and Lore Verhaert "Intergenerational Solidarity and Elder Care in the Low Countries" (2015) 27 CFLQ 285.

21 Crimes (Substituted Section 59) Amendment Act 2007, s 5 (which replaced s 59 of the Crimes Act 1961).

22 Hawthorne v Cox [2008] 1 NZLR 409 (HC) per Heath J, citing Gillick v West Norfolk and Wisbech Area Health Authority [1986] AC 112 (HL). See also Moore v Moore [2014] NZHC 3213, [2015] 2 NZLR 787, where Brown $\mathrm{J}$ dealt inter alia with a dispute over religion and invoked the New Zealand Bill of Rights Act 1990.

23 The father in Ausage v Ausage [1998] NZFLR 72 (FC) did not get away with beating his teenage daughter in the middle of the night. 
Gee, said that "[f]amilies are factories for neurosis". ${ }^{24}$ This factory can continue even when family members are no longer co-residing - as is often true of elder abuse. Can the promotion of family solidarity survive in the face of these realities?

Undoubtedly, in abusive situations, the number one priority must be safety. This may entail the splintering of families and relationships, rather than staying together and putting up with abuse for the sake of some grander scheme. A modernised model would characterise abuse as antithetical to real family solidarity because the enterprise would not be joint, the support would not be mutual and the commitment would not be free. So, in New Zealand the Family Violence Act 2018 (FVA) (which replaced the Domestic Violence Act 1995), OTA and COCA (s 5(a) of which makes the child's safety and protection from violence a mandatory principle) are certainly consistent with family solidarity.

Beyond these first aid measures, the vision must be about healing. This does not mean patching things up and forcing parties back into situations that had become intolerable. It does mean, where possible, some form of rehabilitation and restoration, in particular where parties still have joint responsibilities for children. The three Acts deal with this differently. FVA requires respondents to go to anti-violence programmes; OTA officially places its faith in the family group, whānau, hapū and iwi; while COCA contains rules that emphasise ongoing contact, even if supervised. All three of these approaches have their virtues but do not "talk" to one another very effectively.

The real answer to the challenge of abuse is that this is not true of most families. Family solidarity invites us to consider the bigger picture. It is not limited in its ambit and should be seen as universally applicable. This leads to the next point.

\section{WHY ADD "COMMUNITY"?}

I suggest that in New Zealand we should talk about "family and community solidarity". Families do not exist in splendid isolation but are part of a wider network. Whānau connect to hapū and iwi, and beyond. Pākehā families form links with other families, through all kinds of social and economic activities. Family policy should recognise these realities. Community or state assistance to struggling families and to those who are in need of protection including those who get rest home subsidies is vital. Yet, so are other policies of much more general application such as paid parental leave, the primary and secondary education system and superannuation. Community solidarity goes beyond "social investment"25 targeted at those who are characterised

24 Maurice Gee Blindsight (Penguin Books, Auckland, 2005) at 25, as cited in Atkin "Harmonising Family Law", above n 3, at 483.

25 See Jonathan Boston and Derek Gill (eds) Social Investment: A New Zealand Policy Experiment (Bridget Williams Books, Wellington, 2017). 
as needy, dysfunctional or vulnerable. This is not to deny a significant domain of freedom for families but to recognise that they are socially interconnected.

A further, rather more legal, aspect arises. Lawyers draw a distinction between private and public law. Traditionally it has been made in family law as well, treating breakdown and divorce with their concomitant issues about property and children as "private matters", whereas the state's role is similar to the way it resolves a contract dispute between strangers: largely genuflecting to the autonomy and independence of the parties. Public law's role in family law is restricted, on this view, primarily to where the state intervenes to remove a child into care or take some other form of protective action.

\footnotetext{
Sverdrup challenges this distinction. ${ }^{26}$ She states: ${ }^{27}$

The concepts and mind-set of private law are primarily developed with a view to market relationships and the key question ... is whether they are suitable and equally applicable when the conflict is between two parties in a couple relationship. "Solidarity" may be an apt description of the essential ingredient of the workings of the latter relationship which distinguishes it from others governed by private law principles.
}

And, "[w]hen family law practitioners and scholars look at the couple relationship through this private-law lens, they might only see two persons and not the collective unit." ${ }^{28}$

When we ask about the law's role in relation to the welfare of children, the protection of victims and survivors of domestic abuse, the financial disadvantage of the mother who has been the primary carer of children, the person who lacks mental capacity, and in many other situations, it is unhelpful to fall back on private law rhetoric. Family and community solidarity, it is suggested, is a better driver of family policy.

So, we turn to a closer examination of the current law in New Zealand. I look at two topics: child law and relationship property.

\section{THE LAW RELATING TO CHILDREN}

OTA and COCA are the two main pieces of legislation that deal with the law relating to children in New Zealand. At the same time we have the Status of Children Act 1969, the outdated Adoption Act 1955, the Child Support Act 1991, the Human Assisted Reproductive Technology

26 Sverdrup, above n 13. I have raised similar questions in Bill Atkin "The Revised Family Court System in New Zealand: Secret Justice and Privatisation" in Mavis Maclean, John Eekelaar and Benoit Bastard (eds) Delivering Family Justice in the 21st Century (Hart Publishing, Oxford, 2015) at 39-50; and Bill Atkin "Controversial Changes to the Family Justice System in New Zealand: Is the Private/Public Law Division Still Useful?" (2015) 29 IJLFP 183.

27 Sverdrup, above n 13, at 237-238 (footnotes omitted).

28 At 245. 
Act 2004, the Children's Commissioner Act 2003, the Children's Act, and FVA, which children can invoke. The United Nations Convention on the Rights of the Child is a vital underlying foundation stone, although it has not been fully implemented as part of New Zealand's domestic law. ${ }^{29}$ To list all of these Acts implies a fragmentation of the law and a need for some coherence.

Two developments are encouraging signs that we may partially be heading in the right direction: (i) the Child Poverty Reduction Bill 2018, which heralded changes to the Children's Act, ${ }^{30}$ and (ii) we now have a Ministry for Children, Oranga Tamariki.

\section{A "Vulnerable"}

Let us deal first with the irksome word "vulnerable". The Children's Commissioner, Judge Andrew Becroft, described this as "cripplingly disappointing" when it was included in the original name of the new Ministry. ${ }^{31}$ The adjective has now gone with the change of Minister following the 2017 election. The problem is that the word is aimed at certain children who are believed to be potential candidates for abuse or deprivation and who are thus stigmatised. There is a sense in which all children are "vulnerable" and this is recognised in the publication rules in s 11B of the Family Court Act 1980 which apply to all children and other "vulnerable" persons. However, the use in the context under discussion is a reference to a narrower group of children.

\section{B Child Poverty Reduction Bill 2018 and the Children's Act 2014}

Family and community solidarity embraces all children, not some of them. The Children's Act, as amended during the process of enacting the Child Poverty Reduction Bill, contains a significant change from the original Vulnerable Children Act. It requires the creation of a strategy, the first element of which is "improving the well-being of all children". ${ }^{32}$ Admittedly, the provision also refers to "the well-being of children with greater needs" as being "a particular focus", along with references to child poverty and socio-economic disadvantage and "core

29 Convention on the Rights of the Child, above $\mathrm{n} 4$. The Convention is included in sch 2 to the Children's Commissioner Act 2003 and the Commissioner has functions in relation to the Convention (s 12). See also the Children, Young Persons, and Their Families (Oranga Tamariki) Legislation Act 2017, s 11, which inserts s 5(1)(b)(i) into the principal OTA. The new s 6AA of the Children's Act 2014, as added by the Select Committee during the passage of the Child Poverty Reduction Bill 2018, mentions obligations under the Convention as well as the United Nations Convention of the Rights of Persons with Disabilities, though it also states that this does not "give domestic legal effect to, or implement in New Zealand law" any of the obligations.

30 Part 3 of the Child Poverty Reduction Bill contained amendments to the Vulnerable Children Act 2014 and changed its name to the Children's Act. Part 3 became the Children's Amendment Act 2018. The Child Poverty Reduction Act 2018 itself deals with measurements and targets relating to child poverty.

31 Katie Kenny and Laura Walters "Who named the Ministry for Vulnerable Children, Oranga Tamariki?" (22 October 2016) Stuff <www.stuff.co.nz>.

32 New s 6(1)(a) of the Children's Act (emphasis added). 
populations of interest to the department". ${ }^{33}$ The Bill also used the phrase "at-risk children", ${ }^{34}$ and the Children's Act provides for an "oranga tamariki action plan" that relates to these children. ${ }^{35}$ The content of the strategy as set out in the new s 7 reflects its original location in the Child Poverty Reduction Bill and much of it is about "measurable outcomes" relating to child poverty and socio-economic disadvantage. Nevertheless, the amended Act represents a distinct move from a "vulnerable" class of children to a more universal vision that aligns with family and community solidarity. As the Office of the Children's Commissioner said in its submission on the Child Poverty Reduction Bill: ${ }^{36}$

The purpose [of the Bill] highlights both the need to support the well-being of all children while simultaneously attending to the higher needs of particular groups of children. It encompasses a proportionate universalist approach to well-being, which the evidence supports.

Much of this discussion of the Bill and the revised Children's Act may sound somewhat removed from the classic categories of family law. Yet, if the government has a child strategy, it is surely odd if it has no impact on what family lawyers and other professionals do. By the same token, it would be odd if the strategy failed to take classic family law interests into account. This is indeed a failure of the new legislation. The list above of statutes that deal with child law in New Zealand is far removed from the list in the Act: the amended s 5 specifies FVA, the Education Act 1989, the New Zealand Public Health and Disability Act 2000, OTA, the Policing Act 2008 and the Social Security Act 2018 with a catch-all for other Acts that the GovernorGeneral can add in the future. The departments and instruments of the Crown responsible for these Acts are the "children's agencies" that produce the strategy. ${ }^{37}$ Under the new s 6D, consultation must occur with children or their representatives and with Māori representatives such as iwi and Māori organisations. Wisely, the Select Committee added consultation with the Children's Commissioner.

The list of statutes just noted contains omissions. For example, COCA is not mentioned, yet the welfare and best interests of children when their parents separate should surely be a core feature of any child strategy. Likewise, the list of those to be consulted about the strategy omits the Family Court and allied services such as mediators. In a consummate submission on the

33 Children's Act, s 6(1)(b).

34 Primarily in sch 5, which amended various other Acts and legislative instruments.

35 Children's Act, ss 7D-11.

36 Office of the Children's Commissioner "Submission to the Social Services and Community Committee on the Child Poverty Reduction Bill 2018" at [88].

37 Children's Act, s 5 definition of "children's agencies". 
original version of the Child Poverty Reduction Bill, ${ }^{38}$ the Office of the Children's Commissioner (OCC), which was in general "excited" by the changes to the 2014 Act, referred to the absence of reference of that Office, remedied, as noted above, by the Select Committee. The OCC recommended that the strategy be renamed "New Zealand's Strategy for Child Wellbeing" and proffered its definition of well-being: ${ }^{39}$

We strive toward high levels of child well-being, where all children have the resources and support that is required for them to develop and thrive, able to enjoy their rights, achieve their full potential and participate as equal members of New Zealand society. Child well-being is inseparable from family and whānau well-being.

The link to family and whānau is something that the Select Committee clarified by requiring the Minister in devising the strategy to have regard to the principle that "children should be viewed in the context of their families, whānau, hapū, and iwi, other culturally recognised family groups and communities". ${ }^{40}$ This, it is argued, should reinforce the concept of family and community solidarity.

The Human Rights Commission picked up another gap in the original Child Poverty Reduction Bill. ${ }^{41}$ New Zealand's international obligations, especially the United Nations Convention on the Rights of the Child, ${ }^{42}$ were ignored and the Commission's submission recommended that an additional objective of the strategy should be to advance children's rights under the Convention and other international treaties and instruments. The new s 6A, as added by the Select Committee, now refers to New Zealand's international obligations, and under s 6C the Minister must have regard to children's rights, along with "children's intrinsic value and inherent dignity". This will resonate with family lawyers and other professionals.

\section{The Ministry}

It is good to have a dedicated Ministry for Children, Oranga Tamariki. However, it is more accurately "the Ministry for some things to do with the care of children". Not unlike the Children's Act, it does not bring together all the things to do with children. One totally comprehensive Ministry is not viable, as specialist tasks such as education and health need to stay where they are. However, the classic family law aspects of the care of children arguably should be brought together so that a proper overview of policy can be matched with law-making

38 Office of the Children's Commissioner, above n 36, at [73].

39 At [91] (emphasis added).

40 New s 6C(c) of the Children's Act.

41 Human Rights Commission "Submission to the Social Services and Community Committee on the Child Poverty Reduction Bill 2018" at [37]. See Child Poverty Reduction Bill 2018 (14-1).

42 Convention on the Rights of the Child, above $n 4$. 
that is less contradictory than at present. This includes moving some matters from several other departments, including the Ministry of Justice. The following list of relevant family law areas is a tentative one:

- $\quad$ COCA - this is discussed shortly.

- Responsibility for adoption legislation should be combined with the day-to-day work that the Ministry for Children already does.

- Status of children, currently rather awkwardly spread across various statutes including the Status of Children Act 1969, the Family Proceedings Act 1980 and the Births, Deaths, Marriages, and Relationships Registration Act 1995 (an update is at present before Parliament).

- Human Assisted Reproductive Technology Act 2004. This statute rests with the Ministry of Justice, but the Minister responsible for its operations is the Minister of Health. In truth, much of the Act contains rules about surrogacy, access to records (similar to access to adoption records though broader) and other related matters.

- $\quad$ Child Support Act 1991. There are logistical reasons for keeping the operational aspects with the Inland Revenue Department, but policy should be seen as part of the overall legal framework for children.

- $\quad$ FVA is awkward to deal with. Its main role is to provide for the Family Court to make protection orders between adults, although the police can issue Police safety orders when called to an incident. Arguably, the Act should not be used by or against minors, though minors would still become protected persons on the back of an order granted to a parent. Where something like a protection order is needed for a minor, a beefed up restraining order as found in s 87 of OTA should be used. The value of anger management and other programmes provided for in FVA could be considered for OTA.

Arguably, these changes to the structure of government would assist in the process of developing comprehensive strategies and plans as envisaged by the Children's Act. More generally, the principle of family and community solidarity would underlie the development and implementation of legal policy.

In addition, hopefully some of the awkward tensions present in our current law could be ironed out. These appear in particular between OTA and COCA. The Act that embraces family solidarity most obviously is OTA because of its family group/whānau focus. In some respects, there has been a retreat from this in changes enacted in the Children, Young Persons, and Their Families (Oranga Tamariki) Legislation Act. The new English name of the Act rather pointedly has had the word "families" dropped from its title. The Act has arguably downgraded the role of families and upgraded the place of state and non-governmental organisations under the guise of "early intervention" (worthy though the aim is). Early intervention has replaced "minimal 
intervention", 43 and by definition occurs when a child does not meet the criteria for being "in need of care or protection". ${ }^{44}$ Non-statutory "children's teams" have been created to help the process. ${ }^{45}$ In the absence of a statutory mandate, we cannot really be sure what the future powers and orientation of the teams will be. With luck they will be benign. Perhaps they can be compared to an organisation like Plunket, which offers early assistance to new parents and infants. Plunket's services are however available across the board and not targeted.

Nevertheless, the family group conference remains the legislative centrepiece of OTA, not found elsewhere in our family law. Furthermore, OTA from 1 July 2019 explicitly refers to the United Nations Convention on the Rights of the Child and the United Nations Convention on the Rights of Persons with Disabilities. ${ }^{46}$ Its revised principles in s 5 refer to Māori concepts such as mana tamaiti, whakapapa, and whanaungatanga. The new s 7AA imposes duties on the chief executive in relation to the Treaty of Waitangi (te Tiriti o Waitangi) (see also s 4(1)(f)). These things and more should inform family law more widely, and a broader focus for the Ministry for Children may enable this to happen.

COCA operates on very different models. Instead of the family group conference, COCA relies on family dispute resolution as the main non-judicial mechanism for solving disputes. The paramountcy of the welfare and best interests of the child is the cornerstone, with its added principles in s 5. Somewhat awkwardly, the amendments to OTA in force from 1 July 2019 refer to the child's "well-being" (new s 4A), defined to include "welfare" 47 but leaving its precise legal meaning obscure. COCA led the field with its strong approach to the child's views in s 6 , found in OTA only from 2017 but with more extensive provisions than s $6 .{ }^{48}$ COCA sets out the fundamental role of guardians in the upbringing of children, including the guardianship of the court. Yet OTA emphasises the role of family, whānau, hapū, iwi, and family group in caring

43 OTA, s 13(2)(b)(ii), repealed from 1 July 2019 by the Children, Young Persons, and Their Families (Oranga Tamariki) Legislation Act.

44 OTA, s 14.

45 Oranga Tamariki "Children's Teams" <www.orangatamariki.govt.nz>. The Minister for Children, the Hon Tracey Martin, has since announced the scrapping of children's teams: Andrew Vance "Tracey Martin on uplift controversy: Oranga Tamariki 'believed the child was in danger"' (4 August 2019) Stuff $<$ www.stuff.co.nz>.

46 Children, Young Persons, and Their Families (Oranga Tamariki) Legislation Act, s 11, inserting new s 5(1)(b)(i) into OTA. See the Convention on the Rights of the Child, above $n$ 4; and the Convention on the Rights of Persons with Disabilities 2515 UNTS 3 (opened for signature 13 December 2006, entered into force 3 May 2008).

47 OTA, s 2 definition of "well-being".

48 Children, Young Persons, and Their Families (Advocacy, Workforce, and Age Settings) Amendment Act 2016, s 8, replacing s 11 in OTA. Further additions to s 11 came into force on 1 July 2019. 
and nurturing the child. ${ }^{49}$ OTA also has many provisions relating to guardianship and from 30 June 2016 "special guardianship" was added in language that is demonstrably unclear. ${ }^{50}$ The interplay between OTA and COCA is a minefield.

I have touched on only some of the discrepancies in the current law. The dream is for a Ministry for Children, Oranga Tamariki that can play an innovative role in setting family law policy relating to children that is comprehensive and based on family and community responsibility.

As an important footnote, the Children's Commissioner must remain as a crucial constitutional counterpoint to the Ministry. To fulfil the role properly, the Commissioner should not be appointed on the recommendation of the Minister for Children but should be a parliamentary officer. The functions, staffing and funding of the OCC should also be expanded. ${ }^{51}$

\section{RELATIONSHIP PROPERTY}

When enacted, the Matrimonial Property Act 1976 set New Zealand apart from Australia and England. Some similarities can be found in the laws of Canadian provinces but the parallels with Europe are stronger. The Act is sometimes referred to as a deferred community regime, one where "community property" is shared when the marriage ends. ${ }^{52}$ This echoes the community property regimes found in Europe and parts of the world colonised by European countries, most notably Latin America and some of the states of the United States. ${ }^{53}$ In 2002 when the 2001 package of property and inheritance reforms came into force, the Act changed its name to the Property (Relationships) Act 1976 (PRA) (all the name changing in New Zealand family law legislation must mightily confuse overseas visitors, not to mention locals). The package amended almost every section of the 1976 Act, but two significant policy shifts moved New Zealand away from its European companions: (i) it extended the law to those in de facto relationships; and (ii)

49 Children, Young Persons, and Their Families (Oranga Tamariki) Legislation Act, s 16, inserting new s 13(2)(b) into OTA.

50 OTA, ss 110, 113A and 113B, as inserted by s 22 of the Children, Young Persons, and Their Families (Vulnerable Children) Amendment Act 2014. See CN v Ministry of Vulnerable Children, Oranga Tamariki [2017] NZFC 6962, [2017] NZFLR 963 per Judge Goodwin and Chief Executive of the Ministry for Vulnerable Children v Grant-Shepherd [2018] NZHC 1260, [2018] NZFLR 718 per van Bohemen J.

51 A simple example of an expanded role could be the new complaints mechanism for the Ministry found in OTA, s 7(2)(b), inserted by the Children, Young Persons, and Their Families (Oranga Tamariki) Legislation Act, s 13.

52 AH Angelo and WR Atkin "A Conceptual and Structural Overview of The Matrimonial Property Act 1976" (1977) 7 NZULR 237.

53 On the position in the United States, see Margaret F Brinig "United States: Marital Property" in Bill Atkin (ed) The International Survey of Family Law 2016 Edition (Jordans, Bristol, 2016) 509. 
it provided a mechanism for dealing with financial disadvantage, namely compensation for economic disparity.

Especially in the light of its European links, the original 1976 Act can be seen as a prime example of family solidarity. It operates on the basis that marriage is a partnership of a kind that sets it apart from commercial and property transactions between strangers. ${ }^{54}$ It recognises the different but equal contributions of the spouses to the joint enterprise, and the mark of mutual support. To re-quote Barlow: "[i]t stands in contrast to individualistic notions of autonomy and recognises the altruism which is often required to fulfil its demands." 55 One of its underlying premises is that the parties share the fruits of the marriage, the gains made during their period of cohabitation. Parting company with the classic community property regimes, it takes family solidarity further by treating the family home and chattels as always being within the pool for division. This emphasises the centrality of the home to family life and thus indirectly reinforces the value of non-financial contributions and the interests of children. It also reflects a bit of our legal history: the Joint Family Homes Act 1964 has its origins in the 19th century but was a very important vehicle post-World War Two in providing secure housing for a new generation of families and children, and importantly giving some financial security to mothers. The gender implications of this should not be underestimated. A recent attempt to repeal the Act failed and, given that some of the financial incentives to settle a home as a joint family home have gone, ${ }^{56}$ it is a little surprising that the Act is far from being a dead letter with 86 registrations in 2016, and 36,000 settlements still in existence. ${ }^{57}$

The 2001 reforms can, it is argued, be seen as consistent with family solidarity and indeed are a logical development of the concept. The extension to de facto relationships is a recognition of the social reality that an increasing number of families are non-marital and yet function in the same way as marriages. A "modernised reconceptualisation of family solidarity as a norm at the heart of family law" as Barlow has proposed ${ }^{58}$ readily encompasses de facto couples and their children: it is, after all, "family" solidarity, not "marriage" solidarity.

54 See the magisterial statement of this by Woodhouse J in Reid $v$ Reid [1979] 1 NZLR 572 (CA) at 580583.

55 Barlow, above n 9, at 224.

56 Such as cheap government loans and capitalisation of the family benefit.

57 Law Commission Dividing Relationship Property - Time for Change? Te mätatoha rawa tokorau - Kua eke te wā? (NZLC IP41, 2017) at [31.40] and following. The author was a member of the Expert Advisory Group, assisting the Commission on this project. Contrary to family solidarity, the Law Commission recommended that pre-owned homes should not be relationship property: see Law Commission, above n 5, at [3.66] and following.

58 Barlow, above n 9, at 225. 
The law on economic disparity has proven to be an underachiever and the cause of much litigation. The five judgments from the Supreme Court in Scott $v$ Williams ${ }^{59}$ advance the cause only a little. Finding a solution to the problems associated with the current law on economic disparity was one of the big challenges for the Law Commission and its project on relationship property. That aside however, the policy aim is very much in sympathy with the Barlow vision of family solidarity. The original 1976 Act enshrined equality as one of its cornerstones, a major leap forward from a gender point of view. However, it was soon recognised that formal gender equality was not the same as substantive gender equality because of the significantly disparate income earning capacities of the parties. Modernised family solidarity is concerned with family life as a whole and so, it has no problem with:

... the principle that a just division of relationship property has regard to the economic advantages

and disadvantages to the spouses or partners arising from their marriage, civil union, or de facto

relationship ...

as set out in $\mathrm{s} 1 \mathrm{~N}(\mathrm{c})$ of the Act. The difficulty is not with the goal but with finding a way of achieving the goal.

A little contrary to family solidarity, New Zealand law from the beginning has allowed contracting out. ${ }^{60}$ These are still somewhat awkwardly called "prenups" even though they apply to de facto couples and can be entered at any time before or during a relationship. The court has always had a power to set aside agreements that are unjust but the 2001 reforms elevated the test to "serious injustice" 61 and added, as a factor to which regard must be had, "the fact that the parties wished to achieve certainty ... by entering into the agreement". ${ }^{62}$ Contracting out is an example of exercising autonomy, although it is autonomy for both parties, and, further, the court's power under s 26 to settle property on children overrides autonomy because it is "regardless of any agreement under Part 6". ${ }^{63}$ The United Kingdom Supreme Court accepted the legitimacy of contracting out only as recently as 2010 in Radmacher (formerly Granatino) v Granatino. ${ }^{64}$

59 Scott v Williams [2017] NZSC 185, [2018] 1 NZLR 507.

60 Matrimonial Property Act 1976, s 21, now spread over several sections in pt 6 of the Property (Relationships) Act 1976.

61 Property (Relationships) Act, s 21J.

62 Property (Relationships) Act, s 21J(4)(e).

63 Property (Relationships) Act, s 26(3). This power is rarely used.

64 Radmacher (formerly Granatino) v Granatino [2010] UKSC 42, [2011] 1 AC 534. See Barlow's critique, above n 9 , at 226. 
Lady Hale wrote a powerful dissent that reminds us that such agreements have gender implications and may be oppressive. Referring to the status of marriage, she said: ${ }^{65}$

This means two things. First, the parties are not entirely free to determine all its legal consequences for themselves. They contract into the package which the law of the land lays down. Secondly, their marriage also has legal consequences for other people and for the state. Nowadays there is considerable freedom and flexibility within the marital package but there is an irreducible minimum. ... The question for us is how far individual couples should be free to re-write that essential feature of the marital relationship as they choose.

Later she wrote: 66

...the court hearing a particular case can all too easily lose sight of the fact that, unlike a separation agreement, the object of an ante-nuptial agreement is to deny the economically weaker spouse the provision to which she - it is usually although by no means invariably she - would otherwise be entitled ... In short, there is a gender dimension to the issue which some may think ill-suited to decision by a court consisting of eight men and one woman.

There is certainly something for New Zealanders to ponder here.

This is not the place to proffer a blueprint for an up to date property relationships statute: the Law Commission's 800 plus page Issues Paper, Preferred Approach Paper and final Report testify to how massive the task is. ${ }^{67}$ However, the Law Commission indicated that, while the present Act is no longer fit for purpose, its bones are largely sound ${ }^{68}$ - arguably because they align with family solidarity. The major issues such as economic disparity and trusts (where family solidarity would in general terms endorse the stance of the Supreme Court in the Clayton litigation) ${ }^{69}$ are about ensuring that the right flesh grows on the skeleton.

\section{CONCLUSION}

This article has ranged widely. It has picked up themes like child poverty and elder law in the midst of more traditional family law topics. That is part of the point: family law in the future

65 At [132].

66 At [137].

67 Law Commission Dividing Relationship Property - Time for Change?, above n 57; Law Commission Review of the Property (Relationships) Act 1976: Preferred Approach - Te Arotake i te Property (Relationships) Act 1976: He Aronga i Mariu ai (NZLC IP44, 2018); and Law Commission Review of the Property (Relationships) Act 1976, above n 5.

68 See for example Law Commission Review of the Property (Relationships) Act 1976, above n 5, at [2.40] and following.

69 Clayton v Clayton (Vaughan Road Property Trust) [2016] NZSC 29, [2016] 1 NZLR 551; and Clayton $v$ Clayton (Claymark Trust) [2016] NZSC 30, [2016] 1 NZLR 590. 
has to be seen in its wide context. The vision cannot be narrow. The thread through this article has been family and community solidarity. This motif takes relationships seriously - intimate relationships between adults, parent/child relationships and deep cultural connections. It is a positive image for the future. 
